\title{
THE WEST GERMAN GASTARBEITER SYSTEM OF IMMIGRATION*
}

\author{
Jagdish N. BHAGWATI \\ Columbia University, New York, NY 10027, USA \\ Klaus-Werner SCHATZ \\ Kirl Institute of World Economics, $2300 \mathrm{Kiel}$, FRG \\ Kar-yiu WONG \\ University of Washington, Seattle, WA 98195, USA
}

Received November 1983, final version received May 1984

\begin{abstract}
The paper analyzes the West German immigration system as operated until early 1970 s. Defining the essential features of this system, the authors explain the cross-sectional industrywise utilization of foreign guestworkers during $1964 / 65$ to $1971 / 72$. They also extend the analysis to explaining the sourcewise (by country) composition of foreign workers during this petriod
\end{abstract}

\section{Introduction}

Immigration systems are control systems. Governments attempt with thei aid to restrict and direct the inflow of migrants. Some systems are ostensibly run on 'non-economic' principles: as in the present United States case where 'familiar' and 'refugee' considerations are much the most importart. But other systems, such as the German gastarbeiter system, have been run explicitly on 'economic' lines and thus directly invite sconomic analysis.

This paper is addressed to an economic analy-is of the West Cerman gastarbeiter (i.e., 'guestworker' or foreign worker) $s$, stem. Section 2 states the main features of this immigration system, with a view to defining the key institutional aspects that must determine the manner in which we raust pose our econometric hypotheses. Section 3 then undertakes the analysis of crosssectional industrywise utilization of foreign workers in Germany during the period 1964-1965 to 1971-1972: a period which is argued to be suited to such investigation. Section 4 analyzes a different question: since West

*Thanks are due to German Marshall Fund Grant No. 1-34015 and the Ford Foundation for research support to Bhagwati in undertaking the analysis in this paper. Thanks are due to Joe Altonji, Andre Sapir, Jean Waelbroeck and an anonymous referee for valuable commen ts and to Jungi Shiba for computational assistance. 
Germany gastarbeirers come from different sources (i.e., Yugoslavia, Turkey, Greece, Italy, Portugal, and Spain in the main), what explains the resulting composition of immigrant-inifow into Germany?

\section{The gastarbeiter system: Key features arid consequent hypotheses}

The most important aspect to note in analyzing international, as distinct from internal, migration is that the former is generally subject to controls whereas the latter is generally not. The analysi, therefore, has to grasp clearly the behavior of the government in regard to the conirol of the immigration nows. In analyzing issues such as the overall inflow, the destination-by-sector composition and the source-of-origin composition of immigrants, the precise forms of the immigration system are clearly critical since they must have a decisive impact on these outcomes.

\subsection{Key features of the gastarbeiter system}

The German gastarbeiter system, in the years of its operation until 1973 when major new restrictions were adopted in light of the difficalt macroeconomic situation, was devised and operated during a period of virtually full employment characterized by around $0.5 \%$ unemployment rate. It had, in consequence, the following important features: (i) the government did not impose prior limits (like in the U.S. system for immigrants) on the number of gastarbeiters that would be let in annually; (ii) rather, provided there was no objection from unions and the local authorities. the employers could recruit gastarbeiters from foreign countries, so that tíc annual aggregate inflow was essentially an unplanned aggregate of firmwise decisions; (iii) the importation of gastarbeiters by the firms was then principally via recruitment abroad, with the aid of official recruiting offices in the major source countries; (iv) the ability of gastarbeiters to shift employment away from the initial-recruitment position to other industries and regions was regulated by types of permit and length of stay and was by no means symmetric with the rights of native workers in that regard; (v) German labour law forbade, in principle, the recruitment of foreign labour except at identical wages with native German labour in identical jobs.

While several writers have described the German gastarbeiter system in a way supportive of the critical description above, we might cite Mehrlaender $(1979,1980)$ in brief support. Thus, Mehrlaender $(1980$, pp. 77-78) writes:

'The conclusion of the [Italy-German] agreement on recruitment was preceded, however, vy consultations among relevani German agencies, including the Federal Covernment, representatives of the Federal Employment Agency, the employers and the trade unions. The enployers were interested primarily in reaching a decision in principle to 
encourage recruitment of foreign workers. In contiast, the trade unions foresaw the danger that (non-union) labor might be utilized to keep wages down, and, for that reason, demanded that foreign workers should be accorded the same rights with regard to wages and social benefits as their German counterparts. The unions reached agreement on this point with the Federal Government and the employers' representatives.'

Mehrlaender (1979, pp. 149-150) further writes that:

Residence permits may stipulate geographic areas and time limits. At first, a residence permit is granted for one year only and is tied to designated employment... A foreigner, who has been in Germany, legally, for at least five years and is considered to have integrated himself into the economic and social life, is eligible to receive domicile permit (Aufenthaltsberechtigung). Once granted, the permit aliows its holder to move within the country without restriction... Work permits are issued by the Federal Labor Office (Bundesanstalt für Arbeit). All aliens intending to work in Germany need a work permit. There are two classes of work permits: a general permit, issued normally for one year and geared to the labor conditions prevailing, or to special needs of certain industries; and, there is a special work permit (besondere Arbeitserlaubnis), issued to aiiens who have a sieady employment record for the preceding five years, or who have been living in Germany legally for the last eight years or more, or who are narried to a German citizen. This permit may carry a geographical limitation and is normally issued for five years.'

'Generally following the same steps in the recruitment procedures a German employer first notifies his nearest Employment Office (Arbeitsamt) about his manpower needs... When no Germans are available, the request is routed to the Federal Labor Office in Nuremberg. From there, the appropriate German commission in a sending country is notified.'

\subsection{Implications of these key features: Hypotheses}

Features (i)-(iii) iniply that, as long as there were 'shortages' in the German econoniy for labour, and there were no problems of social unrest resulting from the final magnitude of foreign labour inflow, the government effectively operated with a quasi-open door, letting private firm-level decisions (motivated by joint employer-employee interests) determine the magnitude of the entry through the door. ${ }^{1}$

\footnotetext{
The door w: not fully open since immigrants could not freely walk in but had to be recruited to come into Germany.
} 
This interpretation of the gastarbeiter immigration system, combined with features (iv) and (v), implies immediately that the 'model' that applies in the German case is one where the level and the industrywise composition of immigrant labour are determined by internal 'demand considerations rather than, as in the free-migration models, the interaction of supply and demand factors.

An idealized way to see the essence of this proposition is to consider fig. 1. The foreign-labour supply curve is depicted as $S_{f}$, indicating the availability of labour at wage $W_{\mathrm{F}}$. The domestic supply and demand curves for labo: : are $S_{\mathrm{D}}$ and $D_{\mathrm{D}}$ respectively. (The domestic supply curve might well be made sharply inelastic at higher wages than $\bar{W}$ if we hypothesize that German labour supply 'dried up' at that poin.) If there were free immigration, $Y Z$ amount of foreign labour would come in and the wage would be $W_{\mathrm{F}}$. If a simple immigration quota were set at $Q R$, the wage would be $\bar{W}(>W F)$ and each immigrant would earn a 'rent' of $(\bar{W}-W F)$. The German system can be taken to imply that the employers and employees settle on wage $\bar{W}$ and then recruit labour of quantity $Q R$. Native and foreign labour get the same wage $W$, as required by feature (v) of the system. ${ }^{2}$ It is then evident that if the $S_{F}$

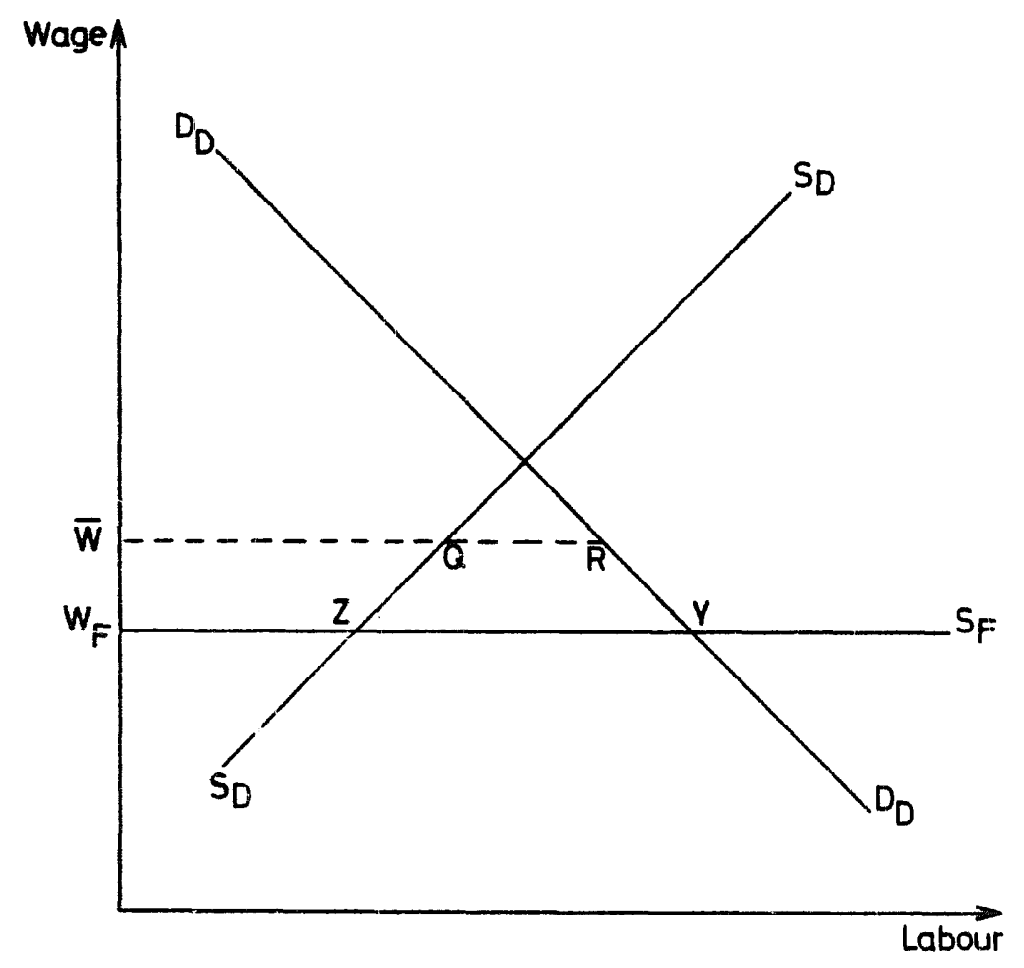

Fig. 1

\footnotetext{
${ }^{2} \mathrm{~A}$ formal recruitmen: model is caller fo: but is beyond the scope of the present paper. We also could formalize the possibility that, despite the law dictating feature (v), effective discrimination takes place against gastarbeiter job reclassification etc. For more analysis of these aspects, see Bhagwati (1982).
} 
curve moves up (but is below $\bar{W}$ ), it will have no effect on the level of German gastarbeiter recruitment and hence inflow: it will simply cut into the gastarbeiters' gain from entering German\%. In this precise sense, we have a 'demand-determined' model of international immigration here. ${ }^{3}$

We thus hypothesize, in section 3 below, that cross-sectional differences among several sectors in the growth of their use of foreign relative to domestic labour during the decade 1964-1965 to 1971-1972 - a period whose choice we justify presently - reflect the cross-sectional differences in factors affecting the growth of demand for them and hence for labour. ${ }^{4}$

How does such a 'demand-determined' immigration system work in regard to the source-composition of immigrants? Let us first note the factors why the results may diverge from those in the free-immigration models, noting next the factors that, however, lead to similar results. If all foreign workers in the German workplace must be paid the same wage, then one could argue that the employers may choose randomly, regardless of wage differences at origin. Therefore, at the plant or firm level, one may expect that, over time, the share of workers from different origins will converge towards the mean (i.e., $1 / n$th if there are $n$ sources). Correspondingly, we may expect that wage differences among alternative sources have no explanatory power; nor may we expect differences in workforce size among alternative sources to te relevant if the choice of workers is truly random. In all these respects, the free-immigration models yield theoretically, as also in econometric studies [reviewed, among others, by Krugman and Bhagwati (1976) to date], opposing conclusions. Wage (or income, current or permanent) differences at different origins do matter. Initial shares tend to diverge rather than converge: 'one Turk leads to another', i.e., information and suppcrtive networks enable those outside the immigration barriers to get inside. And larger workforces at an origin, ceteris paribus, must also imply (like lower wages) a greater inflow into a destination.

But the German model of immigration, once we allow for active recruiting by firms, could still generate results similar to the free-immigration models. For, suppose that lower wage levels and largir workforces imply a relatively greater supply of potential recruits to choose fre.n. Since labour is not homogeneous, it may well be that a better selection of recruits will be available where the pool of applicants is larger. Again, while the information network argument may not hold in the recruitment model, it is possible that

\footnotetext{
${ }^{3}$ This precise and particular meaning and characterization of the concept of 'dernanddetermined' model of international immigration, and its contrast with the usual internal models of migration, were explicitiy discussed in Bhagwati (1979). The concept of demand-determined immigration has also been used by Michael Piore to imply instead a situation where firms in the country of immigration actively recruit labour.

${ }^{4}$ Feature (iv) assures, by reducing reallocative mobility within the country, that primary recruitment would tend to be somewhat correlated with the final sectoral destination of gastarbeiters over this period. But we do not have the longitudinal or other dati. to test this hypothesis properly.
} 
firms may prefer to hire from the sarne source as beiore since the costs of managing workers primarily speaking foreign languages and with specific cultural attributes will increase with the number of sources tapped. As it happens, our results (section 4) support the hypothesis that the recruitment model of German inmigration seems to produce, on balance, source-patterns similar to, rather than different from, those we would expect from the freeimmigration models.

\subsection{Choice of period 1964-1965 to 1971-1972}

The choice of period for analysis is usually dictated in analyses such as ours by the availability of matching data un different variables. In the present case, we have lack of necessary data on the employment of foreigners for the years 1973-1976 because the Federal Office introduced a new registration system in 1973 for foreigners and adopted a new industrial classification, so that employment figures for foreign workers by industry were published again, beginning in 1977 only, and leaving us with data only by broad sectors for 1973-1976. Effective $F^{\prime \prime} s_{\text {, }}$ therefore, we are confined to continuous industrywise data only up to $1-1972$.

However, there is also good and inoived decisive reason to confine our period to before 1973. For, in November 1973, the German gastarbeiter system effectively changed in the restrictive direction. Thus, Mehrlaender (1980, p. 79) writes:

'Until 1973, the Bonn government had left employment of foreign citizens almost entirely to regulatio $t$ by market forces. The recession beginning at the end of 1973 , exa erbated by the oil crisis with its accompanying mass unemployment, caused the FRG [Federal Republic of Germany] to abandon the poli y of entrusting the recruitment of foreign workers to the requirements of industry. A decision to halt recruitment came into force at the end of November 1973, and this approach has been maintained to the present. The continued unfavorable situation of the labor market is the most obvious reason for the current policy.'

These changes are evident in fig. $2 \mathrm{~b}$ where, after 1973, the growth of gastarbeiters in Germany virtually ceases, the new (gross) gastarbeiter inflow reduces to a fraction, and the foreign population also stabilizes.

It follows therefore that one should expect the underlyng model explaining industrywise cross-sectional utilization of gastarbeiters to change after 1973. With the break of such importation since 1973, changes in foreign labour utilization by different sectors would represent virtually reallocations, by and large, of a given foreign labour force rather than, as in the pre-1973 period, largely differential net imports of foreign labour. In fact, our attempts 


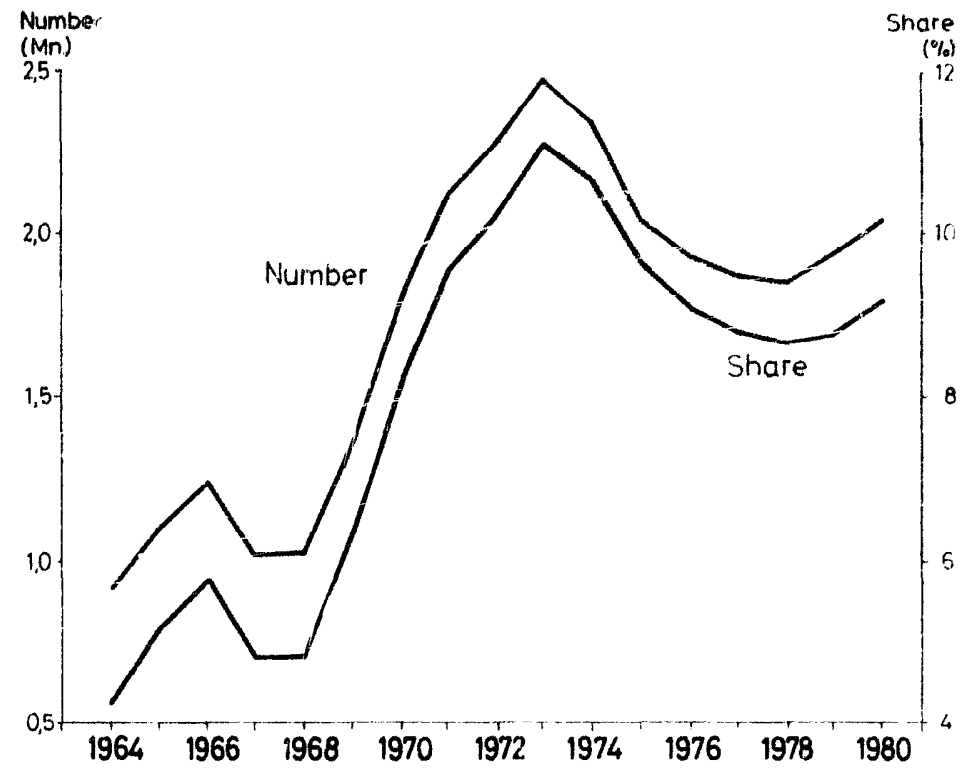

Fig. 2a. Number of and share of foreign wage earners in total wage earners in the Federal Republic of Germany, 1964-1980.

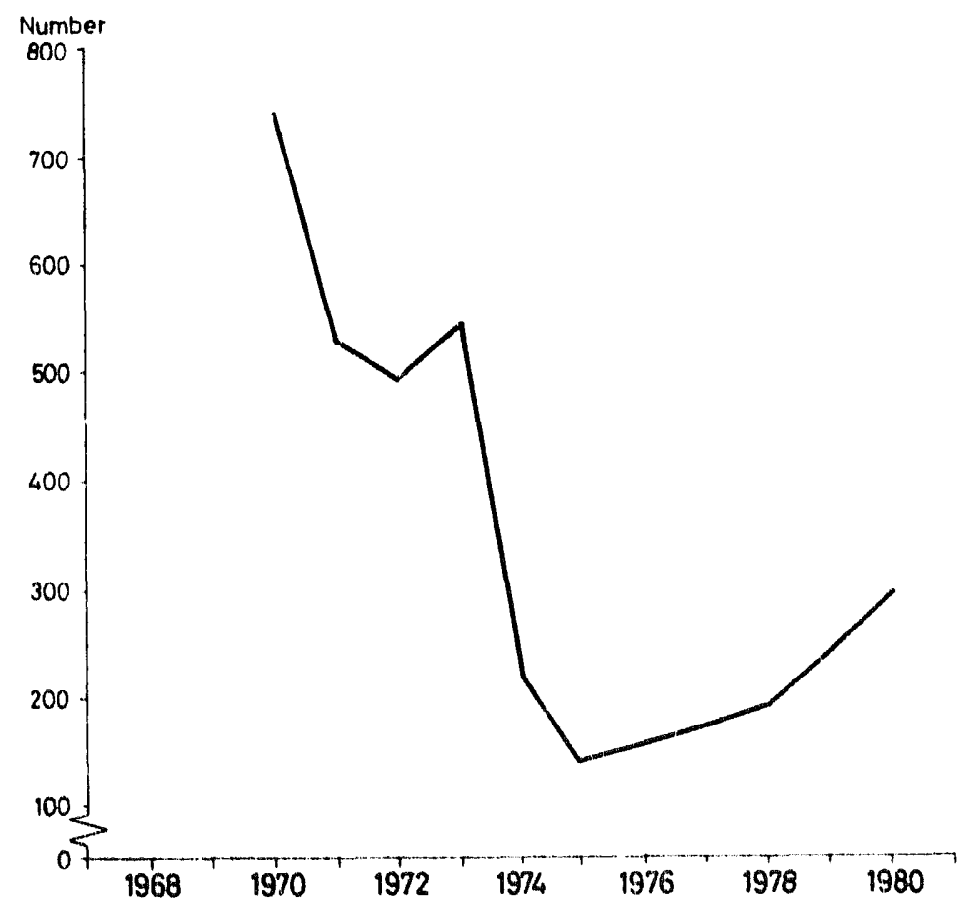

Fig. 2b. Number of foreign workers entering the Federal Republic of Germany, 1968-1980 $(\times 1000)$. 


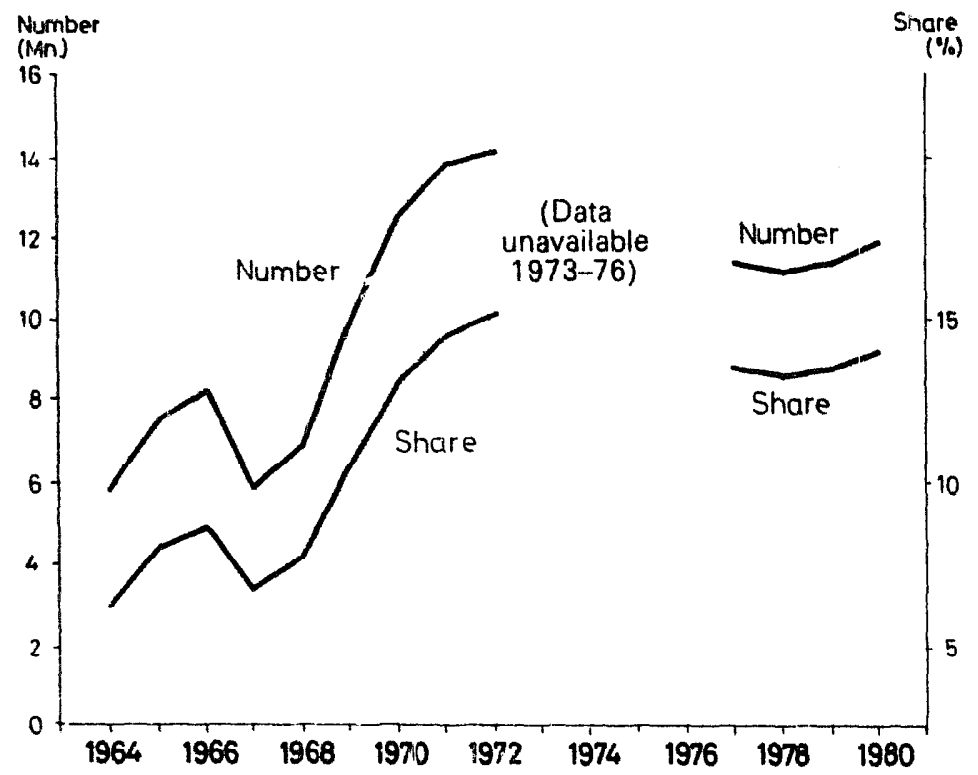

Fig. 2c. Number of and share of foreign wage earners in total wage earners in manufacturing sectors in the Federal Republic of Germany, 1964-1980.

at treating the period 1964-1965 to $1979-1980$ as one period for analysis in section 3 below yielded no results of significance whereas separating the period into two and considering only the earlier period 1964-1965 to 19711972 yielded significant and plausible results: underlining the relevance of our foregoing argument.

\section{The grivwth of gastarbeiters in Germany: A cross-sectional analysis of German industries}

The gastarbeiter system, as discribed in section 2 , makes it plausible for us to test the hypothesis that, cross-sectionally for 'industries' utilizing foreign labour, the rate of growth of such labour utilization would be largely determined by differential growth in their demand.

We therefore used, as our explanatory variables, the change in the degree of protection (both nominal and effective) and the rate of growth of value of output. The reason for including both variables, even though one might think that the output effect would fully capture the effect of the change in the degree of protection, is simply that the period is sufficiently short for the output change of protection cliange not to have worked itself out and the "signalling' effect of the protsction change therefore provides added explanatory power: as in fact the econometric results underline. Besides, profitability of additional hiring seems to be better captured by the change in the value of output, rather than in real output: as again our results indicate. 
We also hypothesized that the growth rate of foreign labour utilization, given the demand factors, would tend to vary inversely with the capitalintensity, especially with capital defined to include skills or human capital: ${ }^{5}$ the search for foreign labour could be balanced in capital-intensive activities by search for capital-using and labour-saving techniques.

We used a 26-sector industry classification, set forth in column (2) of table 1 . Of these, we had to omit sector 54-58 because protection data for it were not available. Sector 33 was also omitted as it is already included in sectors 26-27 and 34. Columns (3) and (5) give the estimated nomiral rates of protection, whereas columns (4) and (6) give the estimated effective rates of protection for these sectors for 1964 and 1972 respectively. Columns (7)(9) and columns (10)-(12) give the capital-intensity data for 1964-1965 and 1971-1972, respectively. Finally, columns (13) and (14) give the value-ofproduction data for 1964-1965 and 1971-1972, respectively.

Table 2, in turn, contains the data on foreign workers, again by our industrial classification, and on total employment within which they are embedded, as also on the source-breakdown by the principal countries of origin, for 1964-1965 and 1971-1972. We should add that these sectors contain virtually $60 \%$ of total foreign workers in Germany during 1964-1972.

We present two main regression results, eqs. (1) and (2), ${ }^{6}$

$$
\begin{aligned}
& \frac{\Delta F}{F}=\begin{array}{c}
113.384+0.7901 \\
(7.9566)(5.6878)
\end{array} \\
& R^{2}=0.6698 \quad \text { adj } R^{2}=0.6203, \quad S E R=25.012,
\end{aligned}
$$

${ }^{5}$ Human capital has been measured, as originally suggested by Bhagwati (1964) and Kenen (1965), as the difference between an industry's actual wage and salary sum per worker and the reward for unqualified labour in the same industry.

${ }^{6}$ As usual, the $t$-statistics are given in parentheses. The variance of $(\Delta F / F)$ is assumed to be dependent on $(1 / F)^{2}$, i.e., the square of the reciprocal of the initial number of foreign workers. The heteroskedasticity in eqs. (1) and (2) is corrected by weighting the explanatory and dependent variables (including the constant term) with the initial number of foreign workers and estimating the equations with the weighted data by the ordinary least squares method. To investigate the sensitivity of eqs. (1) and (2) to the weighting proc dure and the possibility of misspecification, the equations are repeated using the unweighted $r$.ta. The results are reported as follows:

$$
\begin{aligned}
& \frac{\Delta F}{F}=\underset{(5 .(1831)(3.6724)}{121.151+0.5428} \frac{\Delta P}{P}+6.8261 \Delta T_{n}-0.4719 k, \\
& R^{2}=0.5301, \quad \text { adj. } R^{2}=0.4596, \quad \text { SER }=28.903 \\
& \frac{\Delta F}{F}=\underset{(5.0394)(2.9858)}{103.992+0.4814} \frac{\Delta P}{P}+2.8854 \Delta T_{\mathrm{c}}-0.3137 k \\
& k^{2}=0.4991, \quad \text { adj. } R^{2}=0.4240, \quad \text { JER }=29.839 .
\end{aligned}
$$

These equations are not significantly different from eqs. (1) and (2). 
Tatle 1

Industrywise nominal and effective rates of protection, capital-intensity and production, siveral years during 1964-i965 and 1971-1972 (-1:missing value)."

\begin{tabular}{|c|c|c|c|c|c|}
\hline \multirow[b]{3}{*}{$\begin{array}{l}\text { Industry } \\
\text { (1) }\end{array}$} & \multirow[b]{3}{*}{ (2) } & \multicolumn{4}{|c|}{ Nominal and effective tariff protection } \\
\hline & & \multicolumn{2}{|l|}{1964} & \multicolumn{2}{|l|}{1972} \\
\hline & & $\begin{array}{l}\text { Nominal } \\
\text { (3) }\end{array}$ & $\begin{array}{l}\text { Effective } \\
\text { (4) }\end{array}$ & $\begin{array}{l}\text { Nominal } \\
\text { (5) }\end{array}$ & $\begin{array}{l}\text { Effective } \\
\text { (6) }\end{array}$ \\
\hline$(09-11$ & Chemical industry ${ }^{c}$ & $14.3^{2}$ & $18.7^{8}$ & $11.2^{\mathrm{z}}$ & $14.4^{3}$ \\
\hline $12-13$ & Plastics manufacturing ${ }^{d}$ & 17.0 & 18.0 & 11.8 & 8.4 \\
\hline 14 & Stone, sand and clay industry & 7.9 & 11.5 & 3.3 & 3.7 \\
\hline 15 & Fine ceramics & 14.9 & 16.1 & 9.4 & 9.9 \\
\hline 16 & Glass industry & 17.5 & 21.8 & 9.5 & 11.1 \\
\hline $17-18$ & Iron sind steel industry ${ }^{e}$ & 7.1 & 25.9 & 5.1 & 18.3 \\
\hline 19 & Four,dries & 11.9 & $19.1^{\mathrm{b}}$ & 7.7 & $12.1^{\mathrm{h}}$ \\
\hline $.20-22$ & $\begin{array}{l}\text { Stee drawing, cold rolling } \\
\text { nrilis, steel forging }\end{array}$ & 10.2 & 6.7 & 7.6 & 7.7 \\
\hline $23-25$ & Constructional engineering & & & & \\
\hline & and light metal products & 7.7 & 5.0 & 4.0 & 1.4 \\
\hline $\begin{array}{l}26-26 \\
28-30\end{array}$ & $\begin{array}{l}\text { Mechanical engineering } \\
\text { Manufacture of read }\end{array}$ & 9.6 & 3.5 & 6.2 & 2.5 \\
\hline & vehicles & 15.9 & 12.6 & 8.6 & 5.8 \\
\hline 31 & Shipbuilding & 0.8 & -13.4 & 0.4 & -10.1 \\
\hline 32 & Aircraft and aerospace & & & & \\
\hline & industry & 4.0 & -3.0 & 3.2 & -0.9 \\
\hline 33 & $\begin{array}{l}\text { Office and data processing } \\
\text { machines }\end{array}$ & -1.0 & -1.0 & -1.0 & -1.0 \\
\hline 34 & $\begin{array}{l}\text { Electrical engineering } \\
\text { Precision engineering. }\end{array}$ & 11.5 & 8.0 & 7.2 & 4.5 \\
\hline & optics, clocks and watches & 11.5 & $6.6^{i}$ & 7.9 & 4.5 \\
\hline $\begin{array}{l}37 \\
38-29\end{array}$ & $\begin{array}{l}\text { Metal products, n.e.s. } \\
\text { Musical instruments, toys, }\end{array}$ & 13.1 & 12.9 & 7.2 & 5.6 \\
\hline $40-42$ & $\begin{array}{l}\text { jewellery } \\
\text { Sawmills, timber processing. }\end{array}$ & $\$ 3.0$ & 10.2 & 9.3 & 6.9 \\
\hline & wood processing & 13.4 & 19.8 & 7.7 & 10.5 \\
\hline 430 & Pulp, paper and paperboard & 12.6 & 41.3 & 9.4 & 29.6 \\
\hline $431-433$ & Paper manufactures & 17.0 & 24.8 & 13.2 & 19.9 \\
\hline 44 & Printing & 8.8 & 8.4 & 6.1 & 5.3 \\
\hline $45-46$ & Leather and leatherproducts & 16.3 & 24.1 & 7.5 & 9.9 \\
\hline $47-51$ & Textiles & 12.7 & 24.0 & 10.3 & 20.8 \\
\hline $52-53$ & Clothing & 16.5 & 22.3 & 14.0 & 20.7 \\
\hline $54-58$ & Food, drink, tobacco & -1.0 & -1.0 & -1.0 & -1.0 \\
\hline $69-58$ & Manufacturing & 11.0 & 14.8 & 7.4 & 7.7 \\
\hline
\end{tabular}

"Sources: Cols. (3)-(6): Juergen B. Donges, Gerhard Fels, Axel D. Neu, Protektion und Branchenstruktur des westdeutschen Wirtschaft Kieler Studien No. 126 (Tubingen, 1975); Cols (7)-(12): Rolf Krengel et al., Produktionsvolumen und -potential, Produktionsfaktoren des Bergbaus und des Verarbeitenden Gewerbes in der Bundesrepublik Deutschland (Berlin, var. iss.); Cols. (13)-(14): Statistisches Bundesamt, Fachserie 4, Reihe 4.1, Besishaftigung, Umsatz u.a. der Unternehmen und Betriebe im Bergbau und Verarbeitenden Gewerbe, var. iss. - Own calculations and estimates.

${ }^{b} T$ The industry classification follows the German SYPRO classification. However, the deviations in notes $\mathrm{c}-\mathrm{k}$ below must be noted. 
Physical, human and total capital intensity (DM per employee)

\begin{tabular}{|c|c|c|c|c|c|c|c|}
\hline \multicolumn{3}{|c|}{$1964-1965$} & \multicolumn{3}{|c|}{$1971-1972$} & \multicolumn{2}{|c|}{ Production (1000 DM) } \\
\hline $\begin{array}{l}\text { Physical } \\
\text { (7) }\end{array}$ & $\begin{array}{l}\text { Human } \\
(8)\end{array}$ & $\begin{array}{l}\text { Total } \\
\text { (9) }\end{array}$ & $\begin{array}{l}\text { Physical } \\
\text { (10) }\end{array}$ & $\begin{array}{l}\text { Human } \\
\text { (11) }\end{array}$ & $\begin{array}{l}\text { Total } \\
\text { (12) }\end{array}$ & $\begin{array}{l}1964-1965 \\
(13)\end{array}$ & $\begin{array}{l}1971-1972 \\
(14)\end{array}$ \\
\hline 92871 & 42263 & 135134 & 122682 & 86625 & 209307 & 44524609 & 01523709 \\
\hline 27161 & 18706 & 45867 & 37916 & $4106_{i}^{i}$ & 78977 & 8090679 & 18643630 \\
\hline 54147 & 19679 & 69826 & 67455 & 35595 & 103050 & 11568410 & 21514808 \\
\hline 22824 & 11123 & 33947 & 31286 & 37672 & 68958 & 1890850 & 2393930 \\
\hline 28674 & 20753 & 49467 & 45714 & 49843 & 95557 & 2970958 & 5331522 \\
\hline $75996^{\mathrm{J}}$ & $27024^{j}$ & $103020^{j}$ & $98444^{j}$ & $61217^{j}$ & $159661^{j}$ & $2659 / 2498$ & 40417553 \\
\hline $35927^{\mathrm{h}}$ & $19732^{\mathrm{h}}$ & $55659^{\mathrm{h}}$ & 48323 & 54980 & 94283 & 5233577 & 7163998 \\
\hline 48830 & 19813 & 68643 & 61980 & 37888 & 99868 & 9423677 & 13193073 \\
\hline 17780 & 27696 & 45456 & 23075 & 57727 & 80802 & 7733533 & 13016374 \\
\hline 27709 & 26112 & 53821 & 31221 & 57361 & 88582 & 36788657 & 70024026 \\
\hline 48344 & 30409 & 76753 & 53295 & 57330 & 110625 & 25859821 & 61210000 \\
\hline 41414 & 35743 & 77157 & 43103 & 74821 & 117924 & 2589237 & 4492267 \\
\hline 15945 & 35822 & 31767 & 19181 & 86729 & 107910 & 916432 & 2775422 \\
\hline$-1^{k}$ & $-1^{k}$ & $-1^{k}$ & 38056 & 80565 & 118621 & $-1^{k}$ & 5210474 \\
\hline 23617 & 22836 & 46453 & 28689 & 52438 & 81127 & 30038575 & 64817384 \\
\hline 19357 & 18287 & 37644 & 21184 & 36611 & 57795 & 3670559 & 7896087 \\
\hline 22682 & 15293 & 37575 & 34665 & 36439 & 71104 & 14308420 & 21867433 \\
\hline 12324 & 9817 & 22141 & 29957 & 26877 & 50834 & 1725240 & 3217332 \\
\hline 27463 & 14698 & 42161 & 34437 & 31912 & 66349 & 11223418 & 22289501 \\
\hline 78952 & 21781 & 100733 & 98197 & 50705 & 148902 & 4177576 & 5827597 \\
\hline 22769 & 10891 & 33660 & 38463 & 38678 & 74141 & 4796463 & 6203161 \\
\hline 32170 & 17056 & 45226 & 38098 & 48296 & 86394 & 6073305 & 10145127 \\
\hline 16304 & 16875 & 33179 & 28020 & 36818 & 64818 & 5310667 & 6368747 \\
\hline 33207 & 13530 & 46737 & 46067 & 31733 & 77820 & 20356673 & 27166865 \\
\hline 10742 & 3938 & 14580 & 12834 & 11156 & 23990 & 11550085 & 17186636 \\
\hline 68923 & 14072 & 82995 & 79108 & 26722 & 105830 & 51472360 & 86150801 \\
\hline 38641 & 20884 & 59525 & 48891 & 47362 & 96253 & 349886379 & 631897003 \\
\hline
\end{tabular}

'Including mineral oil refinerıes;

"Including rubber and asbestos industry:

'Including non-ferrous metal industry;

'Including repair;

Excluding mineral oil refineries;

'Excluding non-ferrous metal foundries;

'Excluding clock inclustry;

${ }^{j}$ Excluding non-ferrous metal industry;

${ }^{k}$ Included in items $26-27$ and 34. 
Table 2

Employment of foreign workers: Total and source composition, 1964-1965 and 1971-1972 ( -1 :missing valuc).

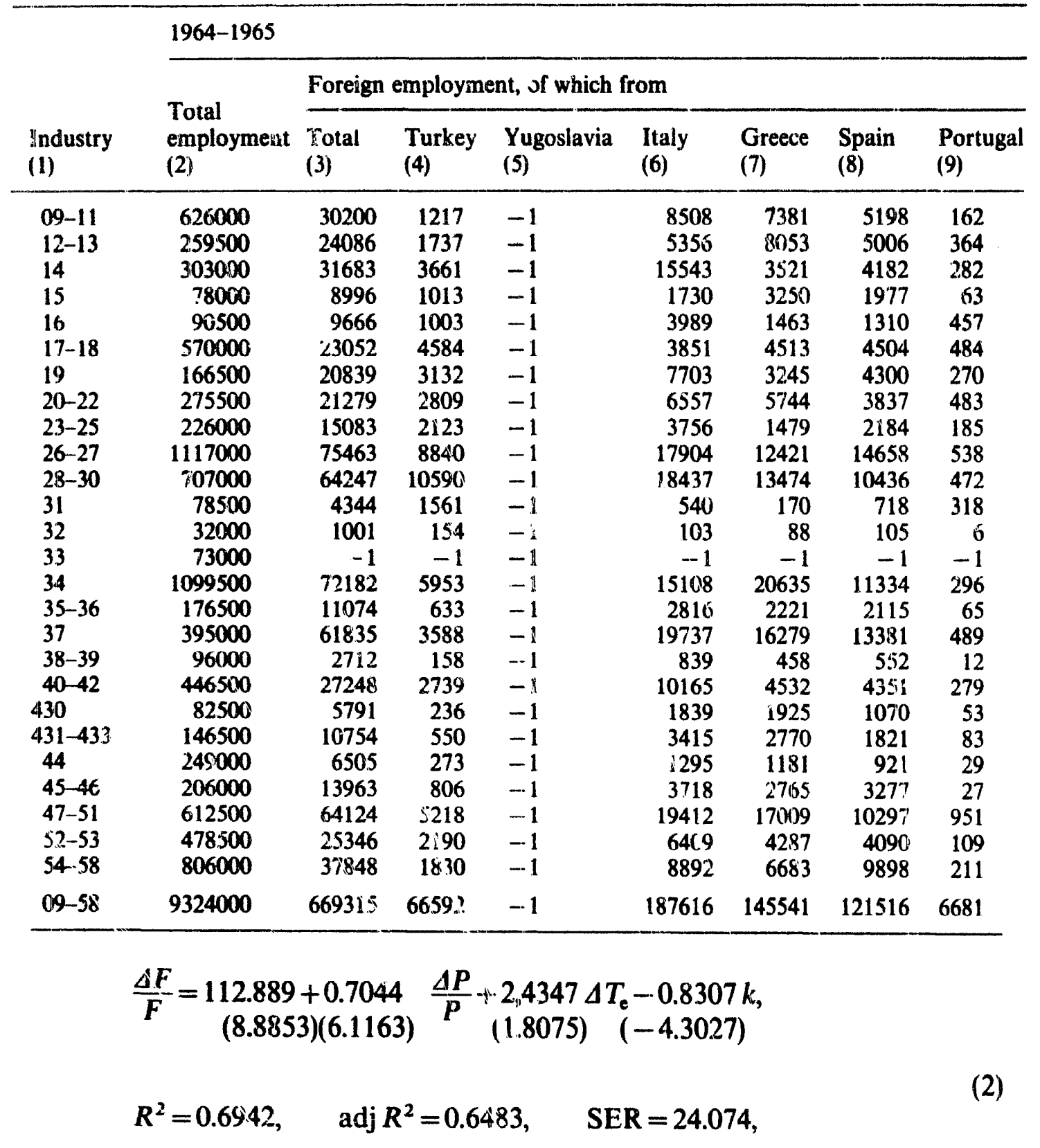

where $F$ is the numive of foreign workers, $P$ is the output of each industry (in 1000 DM), $T_{\mathrm{n}}$ is the nominal tariff rate (in percent), $T_{\mathrm{e}}$ is the effective tariff rate (in percent), $k$ is the capital (physi-al-plus-human)-labour ratio (in $1000 \mathrm{DM}$ per employee) and $\Delta$ represents tite first difference in the relevant variable. All rates of change are expressed in percent.

Eq. (1) uses the change in nominal protection whereas eq. (2) uses the change in effective protection but otherw they are identical. Eq. (1), with 


\begin{tabular}{|c|c|c|c|c|c|c|c|}
\hline \multicolumn{8}{|l|}{$1971-1972$} \\
\hline \multirow{2}{*}{$\begin{array}{l}\text { Total } \\
\text { emiple, nent } \\
\text { (10) }\end{array}$} & \multicolumn{7}{|c|}{ Foreign employment of which from } \\
\hline & $\begin{array}{l}\text { Total } \\
\text { (11) }\end{array}$ & $\begin{array}{l}\text { Turkey } \\
\text { (12) }\end{array}$ & $\begin{array}{l}\text { Yugoslavia } \\
\text { (13) }\end{array}$ & $\begin{array}{l}\text { Italy } \\
\text { (14) }\end{array}$ & $\begin{array}{l}\text { Greece } \\
\text { (15) }\end{array}$ & $\begin{array}{l}\text { Spain } \\
\text { (16) }\end{array}$ & $\begin{array}{l}\text { Portugal } \\
\text { (17) }\end{array}$ \\
\hline 694000 & 55449 & 7646 & 5368 & 12850 & 10828 & 5878 & 1247 \\
\hline 325500 & 61637 & 14597 & 7312 & 10270 & 12983 & 6735 & 3387 \\
\hline 272000 & 43454 & 12520 & 7266 & 11141 & 2637 & 3775 & 1889 \\
\hline 67500 & 14221 & 3408 & 1116 & 2367 & 3226 & 1899 & 538 \\
\hline 97500 & 17878 & 4497 & 1825 & 4437 & 1790 & 1532 & 1751 \\
\hline 462000 & 39537 & 16490 & 3150 & 4406 & 5167 & 3873 & 1848 \\
\hline 14450 & 30152 & 10354 & 3012 & 7170 & 3164 & 3315 & 1159 \\
\hline 263000 & 36496 & 10107 & 4927 & 7502 & 6577 & 3300 & 1847 \\
\hline $18700 \mathrm{~J}$ & 33990 & 6886 & 11548 & 4732 & 2291 & 2211 & 539 \\
\hline 1240750 & 173741 & 39096 & 38747 & 26676 & 22129 & 16355 & 3360 \\
\hline 852500 & 142252 & 39404 & 20205 & 26612 & 24470 & 13268 & 3430 \\
\hline 72500 & 11820 & 5914 & 1721 & 725 & 246 & 759 & 719 \\
\hline 41000 & 2767 & 311 & 202 & 269 & 364 & 290 & 15 \\
\hline 99500 & -1 & -1 & -1 & -1 & -1 & -1 & -1 \\
\hline 1220250 & 182593 & 37769 & 39171 & 25175 & 36998 & 12884 & 1956 \\
\hline $1910 C 0$ & 25869 & 3835 & 6552 & 5454 & 3674 & 2163 & 523 \\
\hline 391000 & 13584 & 25801 & 19328 & 31933 & 28851 & 16257 & 4121 \\
\hline 92000 & 6554 & 1239 & 1262 & 1610 & 979 & 546 & 62 \\
\hline 406000 & 55328 & 13697 & 12147 & 11082 & 5919 & 5375 & 1793 \\
\hline 71000 & 12237 & 1969 & 1839 & 2764 & 3284 & 1338 & 403 \\
\hline 154000 & 22726 & 4594 & 2759 & 5132 & 4726 & 2277 & 629 \\
\hline 264500 & 16154 & 2109 & 2167 & 3087 & 3201 & 1358 & 163 \\
\hline 156500 & 22987 & 4171 & 4420 & 4517 & 3391 & 3052 & 259 \\
\hline 516000 & 117581 & 31934 & 14623 & 23606 & 19998 & 9207 & 8218 \\
\hline 419500 & 55033 & 12943 & 9350 & 12151 & 7914 & 3349 & 1265 \\
\hline 821000 & 81002 & 15812 & 15166 & 12549 & 10916 & 12289 & 2665 \\
\hline 9422500 & 1397317 & 327019 & 235179 & 258211 & 225717 & 133280 & 43778 \\
\hline
\end{tabular}

an $R^{2}=0.67$, and with all estimated coefficients significant, ${ }^{7}$ shows that the rate of change of foreign workers $(\triangle F / F)$ between 1964-1965 and 1971-1972 is positively related to the change in producti $1(\Delta P / P)$ and (not significantly) to the change in nominal protection $\left(\Delta T_{n}\right)$ but inversely related to overall capital-intensity $(k)$. Eq. (2) represents even a marginally better fit, with $R^{2}=0.69$. This equation is also better since the shift to the more appropriate measure of protection, i.e., effective protection, makes the estimated coefficient (2.43) almost significant at the five percent level.

${ }^{7}$ All estimates are significant at a one percent level, ex :ept that the estimated coefficient for $\Delta T_{\mathrm{s}}$ is sigrificant at ten percent level and that for $\Delta T_{\mathrm{n}}$ is not significant. The latter two were, however, included in the equation because we believe that they are important variables to explain the efferts of protection on the inflow of foreign wc rkers. 
Therefore, eqs. (2) clearly dominates, conceptually and by statistical criteria, e(1. (1) and musi be preferred.

The inverse relationship to overall capital-intensity may be discussed further. It presupposes that, the more capital-intensive an industry, the more it will respond to growing demand by economising on labour-use rather than by importing foreign labour, ceteris paribus. I.e., there should be a positive relationship between change in the degree of capital-intensity and capitalintensity in the data. There is, in fart, empirical support for this relationship. For our data, we estimate

$$
\begin{gathered}
\Delta k 17.121+0.3569 k \\
(4.2769)(5.5063)
\end{gathered}
$$

$$
R^{2}=0.5795, \quad \text { adj. } R^{2}=0.5604, \quad \operatorname{SER}=8.5746,
$$

where $k=1000 \mathrm{DM}$ (human + physical) per employee. Other measures of capital-intensity show the same relationship:

$$
\begin{aligned}
\Delta k_{\mathrm{p}}= & 2.3976+0.2312 k_{\mathrm{p}}, \\
& (1.2156)(4.7921) \\
R^{2}= & 0.5107, \quad \operatorname{adj} \cdot R^{2}=0.4885, \quad \text { SER }=5.037, \\
\Delta k_{\mathrm{h}}= & 7.6314+0.9123 k_{\mathrm{b}}, \\
& (2.8052)(7.5466) \\
R^{2}= & 0.7214, \quad \operatorname{adj} . R^{2}=0.7087, \quad \text { SER }=5.279,
\end{aligned}
$$

where $k_{\mathrm{p}}$ is the physical capital-labour ratio and $k_{\mathrm{h}}$ is the human capitallabor ratio.

A word on what we did not find is in order as well. We could not find evidence that differential changes in the availability of domestic workers or their cost as measured by real wages had an impact on the demand for, and hence importation of, foreign labour. Using the real wage rate $(W)$ obtained by deflating by the German CPI and domestic employment $(D)$ for each sector, we obtained the best regressions as follows:

$$
\begin{aligned}
& \frac{\Delta F}{F}=158.072+0.3798 \quad \frac{\Delta P}{P}+1.9165 \Delta T_{\mathrm{n}}-0.9628 k \\
& \begin{array}{llll}
(3.6131)(1.0705) \quad(0.6218) & (-4.5360)
\end{array} \\
& \underset{(-0.1313)}{-0.1091} \frac{\Delta w}{w}+1.0596 \frac{\Delta D}{(1.3615)},
\end{aligned}
$$




$$
\begin{aligned}
& R^{2}=0.7070, \quad \text { adj. } R^{2}=0.6256, \quad \operatorname{SER}=24.83, \\
& \frac{\Delta F}{F}=\begin{array}{ccc}
149.405+0.4328 & \frac{\Delta P}{P}+1.5003 \Delta T_{\mathrm{e}}-0.9090 k \\
(3.4854)(1.1876) & (0.8012) & (-4.2673)
\end{array} \\
& \underset{(-0.2002)}{-0.1657} \frac{\Delta w}{w}+0.7791 \frac{\Delta D}{(0.8390)} \\
& R^{2}=0.7110, \quad \operatorname{adj} R^{2}=0.6308, \quad \text { SER }=24.665 .
\end{aligned}
$$

The coefficients for the real wage rate and the domestic employment are not significant; besides, a rise in domestic employment should have been negatively related to the growth of the foreign labour force. ${ }^{8}$

Next, consistent with our emphasis that the German immigration system implies a 'demand-determined' quota model, we could find no regressions that established a relationship between our dependent variable (or any variations therein) and the differential between the German wages and wages in the source countries of gastarbeiter origin. Moreover, we had been originally prepared to find, instead of the positive relationship between change in degree of protection and change in the growth of foreign labour force, a negative relationship as suggested by the hypothesis of Bhagwati (1982) and Sapir (1983) that the German government may have been more willing to let industries suffering from reduced tariff protection (under policydictated tariff changes as in the Kennedy Round) import more labour. Evidently, however, the government was not playing such a constraining role. As already indicated, the firm's decision to import labour was more or less a sufficient determinant of gastarbeiter inflow during the decade of our analysis, and this implied a positive, rather than a negative, relationship between the two variables. ${ }^{9}$

\footnotetext{
${ }^{8}$ From a theoretical perspective, our demand-determined model suggests also that differential changes in productivity could affect the demand for all, an hence for foreign, labour. Unfortunately, we do not have the necessary estimates of total productivity change to test for this added variable's possible impact. If the variable does matter, its omission from our estimates will create bias in the estimated coefficients. However, we ir ay argue that only the coefficient of the change in output will be biased since we hypothesise that the change in enployment of foreign workers is negatively related to productivity increase and since the change in output is the only variable in eqs. (1) and (2) which is related (positively) to productivity. Furthermore, it follows that if we had indeed been able to manage $t w$ include the omitted variable in the regression equations, the coefficients for the change in output would have been only larger, thus merely reinforcing our findings.

${ }^{9}$ It has been suggested to us by Andrew Sapir that labour-intensive industries, exposed to external competition, could be getting both more protection and be importing more foreign labour. One key element of this hypothesis, however, is empirically refuted. Thus, we can find no significant relationship between labour-intensity in an industry and change in the degree of its nominal and effective protection; the regression results can be obtained from the authors on request.
} 


\section{Soarce composition of gastarbeiter inflow}

Next, we anaiyzed the source composition of workers from five principal supplying countries: Turkey, Italy, Greece, Spain and Portugal. ${ }^{10}$ Again, the data for 24 sectors (excluding numbers 54-58) were analyzed as in eqs. (1) and (2) above. The hypothesis tested successfully was the following

The precise variable chosen as the left-hand side variable in eq. (5), which was estimated, was $\theta_{\mathrm{d}}$, which was the deviation from the mean $(0.2)$ of the share of the incremental inflow of workers from each of the five source countries during the period 1964-1965 to 1971-1972. ${ }^{11}$ Three right-hand side explanatory variables were explored: (i) $\theta_{i}$, the deviation from the mean $(0.2)$ of the share of workers from each country in the base year 1964-1965; (ii) $\theta_{p}$, the deviation from the mean (0.2) of the share of the growth rate of population (as a proxy for the labour force) of each source country during the period 1964-1965 to 1971-1972; and (iii) $\theta_{\mathrm{w}}$, the deviation from the mean of the wage rate in each country in 1971 (since we could not get reliable data for 1964) ${ }^{12}$ After numerous trials, the best fit was yielded by the following equation: ${ }^{13}$

$$
\begin{aligned}
\theta_{d}= & \left(0.8451 \theta_{p}-1.3161 \theta_{w},\right. \\
& (5.6035)(-3.7739)
\end{aligned}
$$

$$
\mathrm{SER}=0.2456
$$

The negative relationship between $\theta_{w}$ and $\theta_{d}$, on the one hand, and the positive relationship between $\theta_{\mathrm{p}}$ and $\theta_{\mathrm{d}}$, on the other hand, can be interpreted as indicating that where the relative wage is lower and the incremental size of the work-force is larger in a source country, the potential pool of applicants available to recruiters of gastarbeiters will be higher and hence recruitment is likely to produce a better, more productive worker for the same (German) wage. However, confronted with the results of many trials, we had to discard the hypothesis that initial shares had any significant effect,

\footnotetext{
${ }^{10}$ The data for Yugoslavia are not available for the early 1970s, so it had to be excluded firom the analysis.

"The deviations are altogether 96 in number since there are 24 sectors and five sources (of which one has to be dropped since it is not independent as the sum of all deviations must total to zero).

${ }^{12}$ The wage data utilised were, therefore, the recorded average wage payments in each industry within each source country (e.g., Thirkey) rather than identical (average) wages in that source country. This procedure implies, of course, that gastarbeiters are more likely to move internationally within the same indiustry: an assumption that may definitely make sense in a 'recruitment' model of immigration as in the present case.

${ }^{13}$ Estimated with a constant tern?, eq. (6) yielded a coefficient which was not significant and bence eqs. (6) was re-estimated, dropping the constant term. Of course, all variables in the equation are in the deviation-from-ihe-mean form so that the summation (over all five source countries) of each variable is equal to zero and hence we shculd theoretically also expect the constant term to be insignificant.
} 
positive or negative, on the source composition of gastarbeiters. ${ }^{14}$ We should have liked to probe this further, at the firm level; but presently the gastarbeiter data are simply not available at that level. ${ }^{15}$ At the present level of aggregation, however, this absence of any significant relationship between $\theta_{i}$ and $\theta_{\mathrm{d}}$ does suggest a difference from the results for some free-immigration ( $r$ al-urban, internal migration) studies that indicate that initial migrant stocks from a source are positively related to new inflows owing to information networks.

Finally, we may remark that there is no inconsistency in principle between our findings that wage differences do not significantly influence the interindustrial gastarbeiter pattern whereas they do affect the source composition. P. esumably, these are not substantial enough to make a difference in the former case and are swamped wholly by the direct demand factors such as rate of growth of output or change in protection, whereas they are substantial enough to affect the recruitment pool and thus get reflected in the statistical results for the latter case.

\section{Concluding observations}

Our results suggest strongly that the econometric analysis of international immigration (quota) systems must reflect the institutional features that characterize them. These features vary, not merely across countries (e.g., the USA and W. Germany) but also, as in the German case before and after 1972-1973, within a country at different points of time. Again, this implies possible differences from the results expected and observed for the freeimmigration studies relating to internal migration within countries, though the specific features of the quota-systems operated by internationalimmigration authorities can equally generate some similarities (as in section 4 above).

\footnotetext{
${ }^{14}$ It may be mentioned that, since 1968, Italian workers could come in freely under the EEC rules. However, it is widely believed that the bulk of the Italian inflow into Germany continued to take place subject to a job being first offered in Germany.

${ }^{15}$ The importance of $t$ " further probing may be seen from one example. Assume that, in a 2firm industry, one firm : iandomly) hires Turks initially and the other hires Greeks. Let the 'Turkish firm' be bigger than the 'Greek firm'. Now, let each firm hire more of the same, for reasons spelled out in the text. So, the Greek firm hires and more Greeks and the Turkish firm hires more Tuiks. But add now the assumption that all firms are on an expansion path which decelerates over time. Then, in a 2-period model, the faster growth of the smaller Greek firm will suffice to lead to converging shares at the industry level in source-composition of gastarbeiters! Thus, at a (firm or plant) micro-level, the recruitment model may be working exactly like the free-immigration model but the industry-level data may suggest the opposite! Evidently, we must await micro-level data to test for this.
}

E.E.R $\cdots$ B 


\section{References}

Bhagwati, J.N., 196\%, The pure theory of international trade: A survey, Economic Journal, March, reprinted in: R. Feenstra, ed., International factor mobility: Essays in international economic theory, Vol. 2 (MIT Press, Cambridge, MA) ch. 59:

Bhagwati, J.N., 1979, The economic analysis of international migration, Plenary lecture delivered to Nordisk Migrasjonsforskerseminar, Nordic Council of Ministers, Oslo, Norway, in: R. Feenstra, ed., International factor mobility: Essays in international economic theory, Vol. 2 (MIT Press, Cambridge, MA).

Bhagwati, J.N., 1982, Shifting comparative advantage, protectionist demands, and policy response, in: J.N. Bhagwati, ed., Import competitiun and response (MIT Press, Cambridge, MA) 153-195.

Kenen, P.B., 1965, Nature, capital and trade, Journal of Political Economy 73, no. 5, 437-460.

Krugman, P. and J.N. Bhagwati, 1976, The decision to migrate, in: J.N. Bhagwati, ed., The brain drain and taxation (North-Holland, Amsterdam) 31-51.

Mehrlaender, U., 1979, Federal Republic of Germany, in: D. Kubal, U. Mehrlaender and E. Gehmacher, eds., The politics of migration policies (Center for Migration Studies, New York) 145-162.

Mel:rlaender, U., 1980, The 'human resource' problems in Europe: Migrant labor in the Federal Republic of Germany, in: U. Ra'anatn, ed., Ethnic resurgence in modern democratic states (Pergamon, New York) 77-100.

Sapir, A., 1983, Foreign competition. immigration and structural adjustment, Journal of Interaational Economics XIII. 